\title{
The Digital Revolution and the Organization of Work: Contemporary Management Techniques
}

\author{
Michael J. Kendzia, Albena Björck \\ ZHAW SML, Winterthur, Switzerland \\ Email: kend@zhaw.ch, bjoe@zhaw.ch
}

How to cite this paper: Kendzia, M. J., \& Björck, A. (2018). The Digital Revolution and the Organization of Work: Contemporary Management Techniques. Advances in Applied Sociology, 8, 212-232. https://doi.org/10.4236/aasoci.2018.83013

Received: January 13, 2018

Accepted: March 12, 2018

Published: March 15, 2018

Copyright $\odot 2018$ by authors and Scientific Research Publishing Inc. This work is licensed under the Creative Commons Attribution International License (CC BY 4.0).

http://creativecommons.org/licenses/by/4.0/

(c) (i) Open Access

\begin{abstract}
Viewed from a global perspective, the digital revolution affects organizations as well as individuals. For present purposes, the digital revolution refers to the transformation process of analog data into a digital format. The key driver behind this process seems to be the technological progress in particular within the information and telecommunication industry. To ensure both productive and attractive jobs during times of rapid change, an efficient allocation of work gains in importance. Nonetheless, owing to the strong trend towards digitalization, a window of opportunity for flexible solutions at company level opens. Before this backdrop, the paper addresses in particular the area of knowledge- and project-based work within the service sector. By doing so, the paper attempts to set out where the technological forces and trends are leading the organization of work and what the contemporary management can do to better adapt to this development. To do so, an interdisciplinary research approach is followed, including aspects from labor economics, occupational psychology and business administration. Finally, the investigation identifies concrete management techniques to provide proper tools to meet the demands of modern workplaces.
\end{abstract}

\section{Keywords}

Digitalization, Technological Progress, Autonomy, Intrinsic Motivation

\section{Introduction}

Owing to the need of companies for innovations in a rapidly changing business environment, companies face tremendous challenges regarding the optimal adaptation to the so-called "digitization of everything". For present purposes, the digital revolution refers to the transformation process of analog data into a digital format. The key driver behind this process seems to be the technological 
progress in particular within the information and telecommunication industry.

Main contributions to this topic were made by Brynjolfsson and McAfee (2014), pointing out that technologies would race further ahead, whereas not only the individual's skills but also larger organizations would lag behind in development (Brynjolfsson \& McAfee, 2014, 2011). At the same time, it is evident that both authors refer to the book "The New Division of Labor" by Levy and Murnane (2004), describing how computers might create the next job market. More specifically, the authors attempted to exhibit tasks that were better performed through humans than by computers. Likewise, the same authors shed light on tasks that were carried out better by computers than by humans. According to them, computerized work has enhanced the role of critical thinking by, for instance, identifying and solving uncharted problems (Levy \& Murnane, 2004).

However, the idea addressed in this article is far from being a new phenomenon: in 1960, Herbert Simon wrote an essay on "The corporation: Will it Be Managed by Machines?" The later Nobel Prize winner pointed out that computerized work would not immediately trigger mass unemployment. In contrast, computerized work would lead to shifts in the economy's mix of jobs. According to his assessment, more people than ever would work in a personal service sector, involving face-to-face human interaction (Simon, 1960).

Nevertheless, a closer link between both aspects, dealing with applied approaches as to how to cope best with the changing requirements of management techniques resulting from the digitalization process, is relatively rarely covered. Against this backdrop, this article seeks to analyze the addressed link by exhibiting data on this issues and attempts to recommend both concrete and contemporary management methods. Yet, as the concrete impact of the development of information and communication technology on workplaces and individuals will be part of continuous scientific investigations, the scope of this article is still limited.

Figure 1 reveals information about the internet use across Member States of the European Union. Persons aged 16 - 74 using the internet at least once a week are classified as regular users, whereas persons not meeting the aforementioned criterion belong either to the group of occasional users or, in case of not using the internet at all, are classified as group "never". According to the data, among the top five member states are the Netherlands, Sweden, Luxembourg, Denmark, and Finland, while the Members States with the lowest rates of internet use encompass Romania, Bulgaria, Greece, Italy, and Portugal.

By analyzing the use and range of activities more in-depth, Blank and Groselj (2014) find that those participating in most internet activities can be described as young, well-educated, and employed (Blank \& Groselj, 2014). However, Brynjolfsson and McAfee (2014) voice the concern that common workers will not be in a position to adapt to the increasing speed of the technological change (Brynjolfsson \& McAfee, 2014). 
Regular internet use in 2012 (\% of individuals)

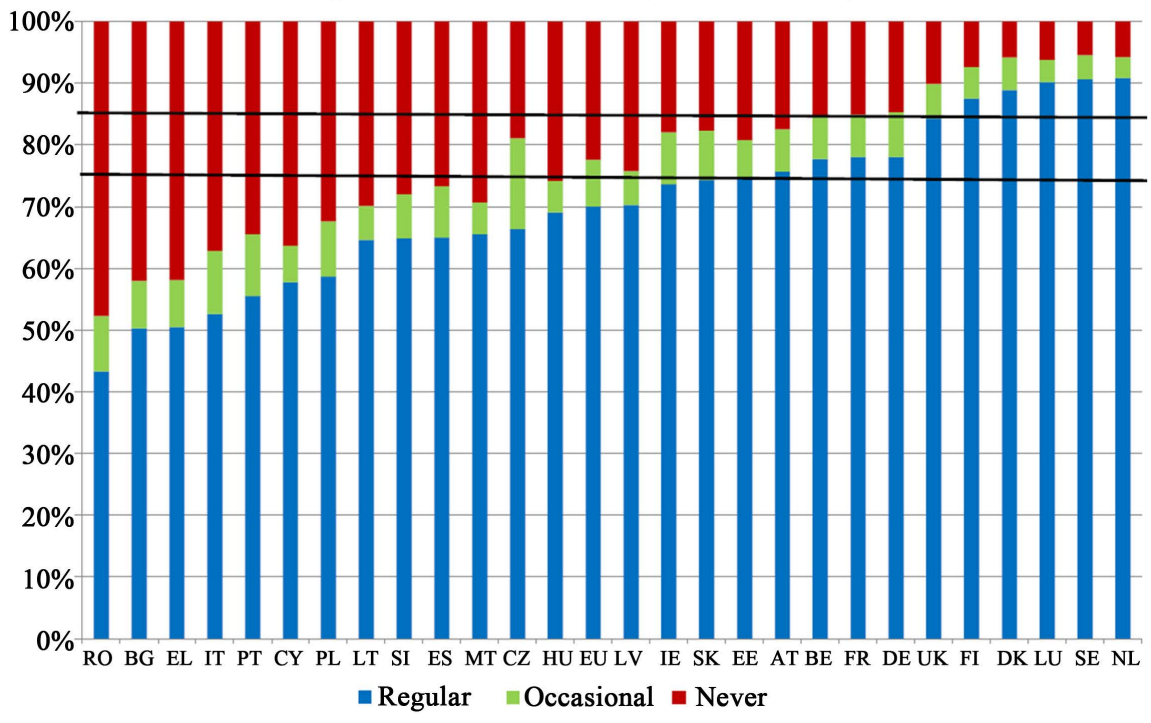

Figure 1. Internet usage across the EU in 2012. Source: European Commission (2013). Note: Persons aged 16 - 74 using the internet at least once a week or never; the rest is classified as occasional users; horizontal lines represent targets of the European Commission.

Nonetheless, the same authors further elaborate that workplaces need time to adjust to technological changes and-after a certain while-as a result, stronger growth occurs (Frey \& Osborne, 2015). With this said, and in contrast to earlier times, when a farmer had to stop working on the field, due to natural borders, today, in the course of electrification and permanent connectivity, an employee does not face any kind of timely restrictions. Against this background, the authors attempt to set out that management skills become more and more important to assess both one's own productivity and the need for rest phases.

However, fears and causes of concerns regarding the future are nothing new. Malthus (1798) already proclaimed that the population would grow much stronger than the agricultural supply. Consequently, this fact would lead to famine amongst the entire mankind. Others, such as Rifkin (1995) announced the end of work, whilst recently Piketty (2014) foresaw growing wealth inequalities due to capitalistic regimes.

Here, a rather positive approach is followed setting out as to how to cope with the technological change. To ensure both productive and attractive jobs during times of rapid change, an efficient allocation of work gains in importance. Nevertheless, due to the substantial trend towards digitization, a window of opportunity for flexible solutions regarding the organization of work opens.

Thereby, an interdisciplinary research approach is followed, including aspects from labor economics, psychology and business administration. Moreover, this paper seeks to reveal proper management skills to cope with the increasing demands through the digitization at the individual level. At the same time, the article aims at explaining how organizations may create and manage today's 
workplaces to adapt to these changes successfully.

To do so, first of all, the latest assumptions and models in this area are shown within the theoretical framework. Thereafter, empirical results from various international as well as European institutions are displayed, as this paper focuses mainly on the Member States of the European Union. However, during the empirical part, latest management approaches from the US need to be taken into account.

By doing so, the so-called open method of coordination (OMC) is applied. Subsequently, this paper sheds light on the self- and management techniques of those Member States performing best. Finally, contemporary features of organizations meeting the raising demands in the workplace are presented.

\section{Theoretical Evidence}

By investigating the shift of risks and responsibilities from the employer to the employee, Pinchot (1985) developed the expression of the intrapreneur. According to him, employees should not leave the company to become self-employed. Rather, he recommends a mixture of intracorporate activities and entrepreneurship-the so-called entrepreneur on the job, or intrapreneur. This would allow organizations to adapt quickly to changing demands.

Research has intensely been dealing with the concept of perceived autonomy or rather control at work. Autonomy in this respect is defined as the individuals' amount of direct or indirect influence concerning its environment. Here, in particular the individuals' creation of a less threatening and at the same time more rewarding environment is taking into account (Sparks et al., 2001).

The adverse effect on the individuals' health and well-being in terms of lacking autonomy has been shown in various investigations (Averill, 1973; Miller, 1979; Ganster \& Fusilier, 1989; Evans \& Carrére, 1991). While autonomy in carrying out a task, might serve as a stress buffer, as noted by Terry and Jimmieson (1999). Luchman and Gonzalez-Morales (2013) illustrate the process of mental exhaustion as follows: Firstly, increasing job demands result in a perceived lack or potential loss of personal resources. Secondly, this perception, in turn, leads to psychological and physiological arousal, triggering the activation of the so-called sympathetic nervous system. Lastly, in the course of time, the psychological and physiological activation reduces the mental and emotional resources of the individual. Consequently, a loss of energy or health impairment might occur.

Therefore, to decide as to how a specific task or job shall be fulfilled, including the freedom to determine start and finish times, reflects a fundamental human need. Thereby, work or the workplace itself becomes rewarding and thus motivational. In contrast to being directed to do a certain activity, as Hackman and Oldham (1975) reveal, individuals who perceive themselves as deciding what exactly to do, take more self-responsibility and show higher degrees of intrinsic motivation (Sparks et al., 2001). 
Later research on this topic has shown that, both autonomy and intrinsic motivation within work tasks lead to a high degree of satisfaction particularly in non-routine work such as project work. This assumption is represented by the self-determination theory (Deci \& Ryan, 2000, 1985). Likewise, Kalleberg and Vaisey (2005) summarize that autonomy contributes to a large extent to the workers' assessment in view of their job to be of high quality (Gallie \& Zhou, 2013).

Autonomy can be associated with the phenomenon of a considerable degree of decision latitude (Karasek, 1979). In this context, Stansfeld and Candy (2006) concluded within their meta-analytic study that job strain resulting from both high psychological demands along with low decision latitude entails a high risk for mental ill health. The same holds for high effort at work and low reward-the so-called effort-reward imbalance (Stansfeld \& Candy, 2006).

According to the International Labor Organization (ILO), autonomy can be interpreted as the manifestation of the individual's right to freedom and dignity in the workplace. More concretely, Deci and Ryan (2007) understand autonomy as "to endorse one's actions to the highest level of reflection". Thereafter, individuals perceive themselves as acting autonomously when they are free to choose to do those things which are meaningful and interesting to them. Furthermore, autonomy is attributed to one of the basic psychological needs and must be met to act optimally as a human being. Plus, in particular job autonomy appears to be closely related to self-efficacy, flexibility, and organizational commitment. In this article, autonomy refers to how work is structured, organized, designed, and managed (Gagné \& Bhave, 2011).

Nevertheless, and far more specifically, the authors concentrate on the organization of the workplace and management techniques. Autonomy seems to be very closely related to higher forms of work motivation, productivity as well as personal well-being (Gagné \& Deci, 2005). Additionally, it has a long-term impact on intrinsic work motivation, as shown by Wall et al. (1986).

Another phenomenon contributing to the increased perception of autonomy constitutes the participative management style. Here, this is understood as the allowance to participate in as employee in the decision-making process. Hackman (1986) defines participative management as the 1) the authority to execute their work how they like to do it and 2) manage and monitor their own work. Moreover 3), according to his approach, people are allowed to design and distribute their work and finally 4) set their own goals for their unit or organization (Gagné \& Bhave, 2011).

\section{Empirical Evidence}

To explain the underlying method used to analyze the respective outcomes of the various Member States of the European Union, the authors use the aforementioned OMC. This approach constitutes a new governance architecture and allows Member States and European institutions to compare their performance 
in areas which are, from a labor market perspective, rather touchy and therefore controversially discussed.

This can be shown by Figure 2, indicating the various responsibilities of labor market issues throughout the entire Union. Whereas human rights issues and questions related to corporate social responsibility can only be negotiated at global level, the European Union has a rather limited impact on labor market issues, including questions regarding training, mobility, or amongst others, health \& safety. That is, the core elements of each employment contract today are still negotiated at national and local level, containing dismissal protection and-the heart and soul of each contract-such as wages and working time issues.

\subsection{The Open Method of Coordination}

As the European Union cannot directly influence any of the central characteristics of employment contracts, the Union and its related institutions can only vaguely address certain issues related to the labor market by using the OMC. In general, the OMC is applied where the Treaty base for EU action is weak. It includes guidelines rather than hard-law directives at EU level and assesses performance against objectives. Based on benchmarking, it leads to the exchange of good or even best practices.

The European Social Survey investigated the extent of one's own job control. Here, people were asked "how much the management at your work allows you

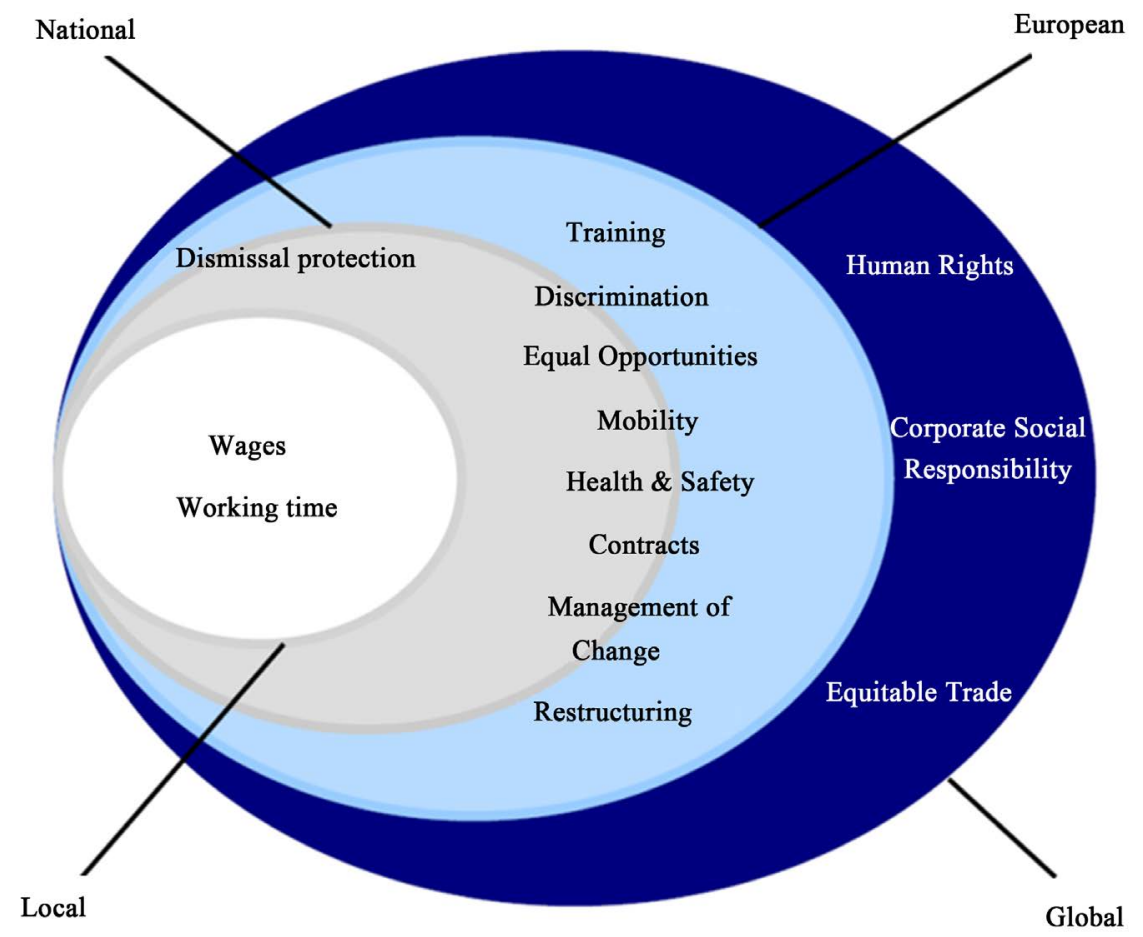

Figure 2. Labor market responsibilities within the European Union. Source: Eichhorst et al. (2011). 
1) to decide how your own daily work is organized; 2) to influence policy decisions about the activities of the organization; and 3) to choose or change your pace of work." The questioned people could respond on a ten-point scale, ranging from 0 (no influence at all) to 10 (complete control over my work task) (Gallie \& Zhou 2013). As illustrated by Figure 3, the Scandinavian countries, here including Norway, achieved the best results in this respect. As the Netherlands are associated with the Scandinavian countries in this article, even the Netherlands show high level of work control by the individual, according to the latest figures from 2010.

Having said this, the present article applies to this approach and refers to data stemming mainly from sources of the European Commission, Eurostat, and the OECD. As data from Eurostat indicates, many jobs in Scandinavian countries, such as Denmark, Finland and Sweden as well as in the Netherlands, appear to meet the demanding requirements of today's workplaces.

When looking at today's challenges at the workplace and in accordance with data provided by the OECD (2014), it appears that Scandinavian countries do not only show low job strains, as Figure 4 reveals, but also tend to exhibit in general higher levels of factor self-responsibility.

Based on data from the European Commission (2014), the latter relationship between self-responsibility and less strict deadlines is shown in Figure 5. These results are affirmed by similar investigations, pointing to lower degrees of control through a supervisor in Scandinavian countries.

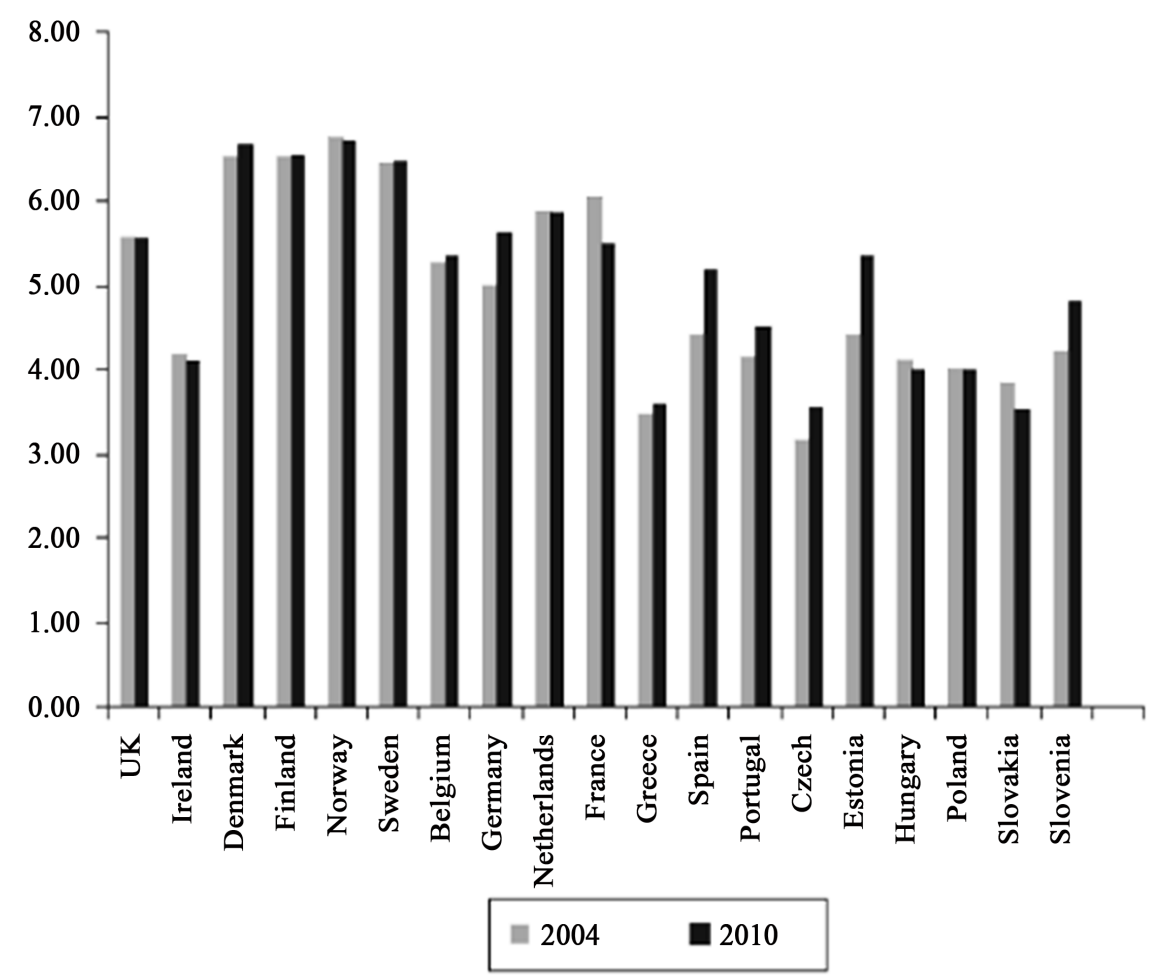

Figure 3. The individuals control over the work task. Source: Gallie \& Zhou, 2013: p. 117. 


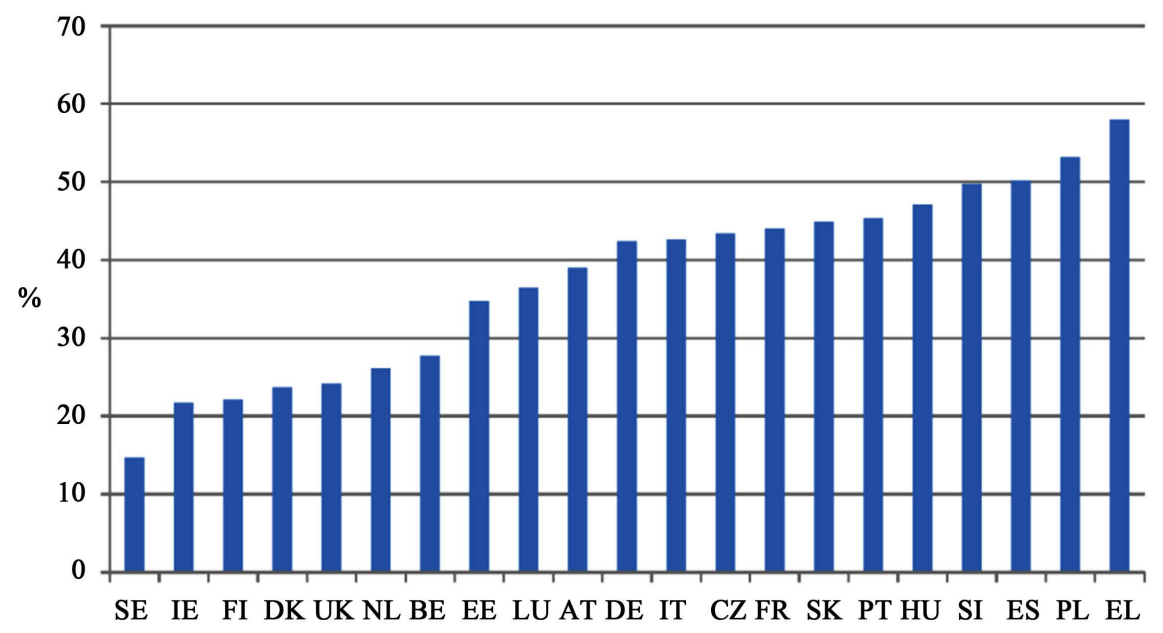

Figure 4. Summary index on job strain. Source: OECD 2014 cited from Eichhorst, W. (2015).

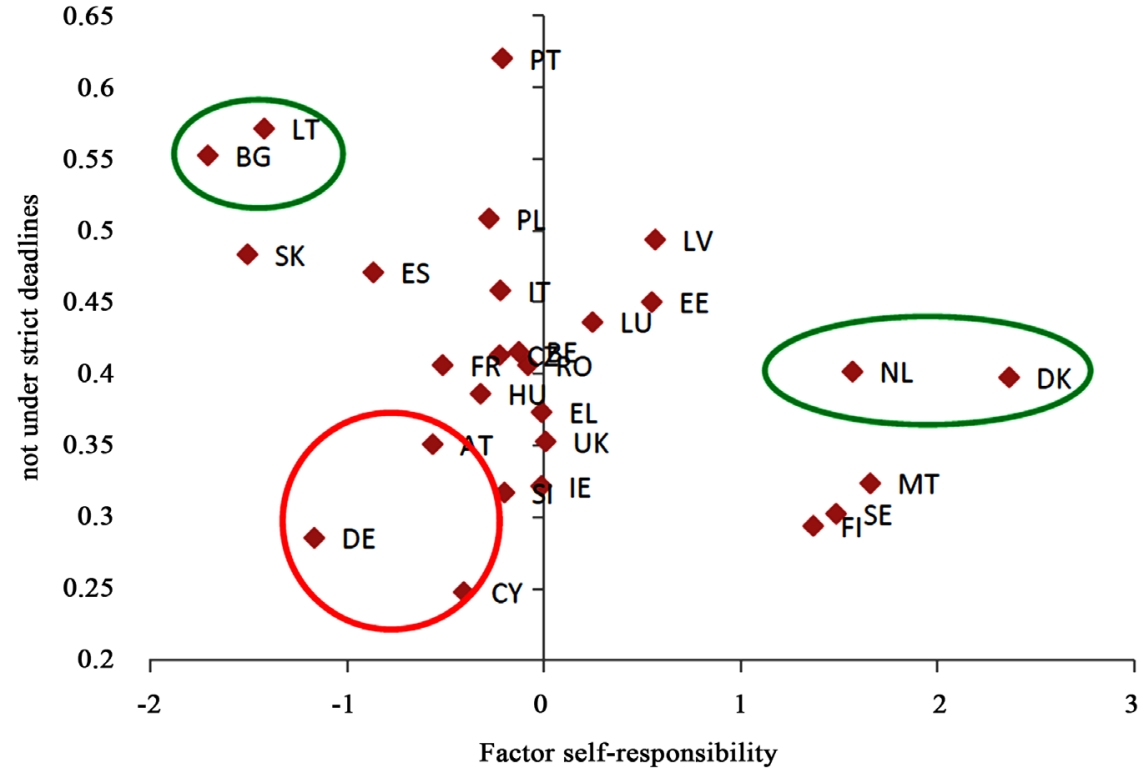

Figure 5. Tough deadlines and self-responsibility. Source: European Commission (2014) based on Eurofound cited from Eichhorst, W. (2015). Note: high stress marked in red, low stress in green.

According to data from the European Commission (2014) and as displayed in Figure 6, the group of the above mentioned countries exhibits also the highest participation rates in terms of lifelong learning in a European comparison. Thus, these countries seem to be exemplary for the organization of work based on empirical insights. Thereafter, other countries appear to have a certain potential in modernizing the organization of work to meet future demands.

These empirical findings are particularly relevant for knowledge- and projectbased work. To cope with the challenging competitive environment in this area of work, both the educational attainment and lifelong learning become increasingly important. As management tasks are today much more complex 


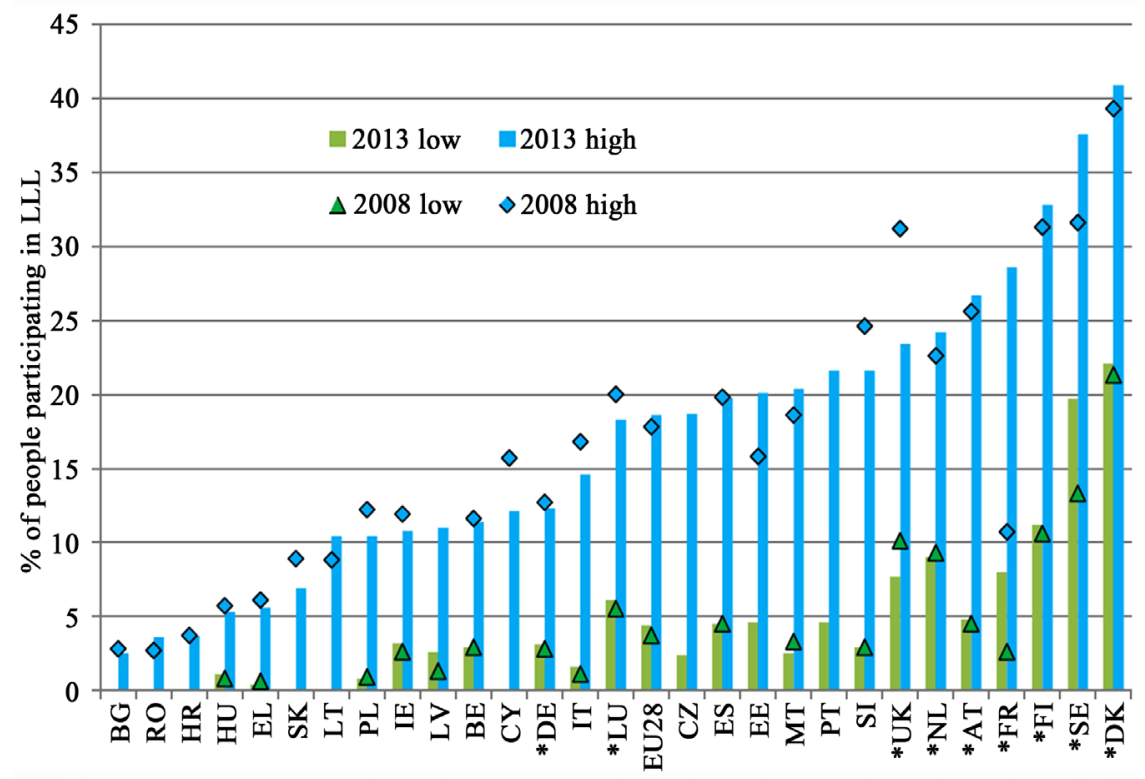

Figure 6. Participation in lifelong learning at different skill levels. Source: European Commission 2014, based on ELFS cited from Eichhorst, W. (2015).

compared to the scenario in the last century, psychological issues in terms of stress, potential exhaustion and mental health have to be taken into account.

However, the demand for managerial expertise has grown and so has the complexity of management techniques facing the implications of the broad digitization process. Generally, management techniques can be defined as "appropriate methods of managing”, which contribute to developing a productive job. Here, the analysis concentrates on personnel management.

\subsection{The Scandinavian Management Model}

Further investigations in view of the Scandinavian Management Model conclude that this model can be characterized by relatively strong degree of cooperation and consensus, a participative leadership style (decisions are made via democratic processes), a strong tendency towards harmony and thus an attitude of conflict avoidance. Also, it is worth noting that formal authority is rejected and enormous emphasis is put on the interpersonal orientation (empathy) (Grenness, 2011, 2003; Zemke, 1988).

The same authors compile a SWOT-analysis (Grenness, 2011, 2003; Zemke, 1988), based on interviews with Scandinavian managers, categorizing the individual's citation as shown in Figure 7.

As a much larger share of the population attends college and work in idea-generating industries than was the case 50 years ago (Frey \& Osborne, 2015), more flexible solutions as regards the organization of workplaces seem to gain importance.

Against this backdrop, the participative leadership style of Scandinavian countries might serve as a role model for future forms of management, facing the increasing demands of the digitalization process. 


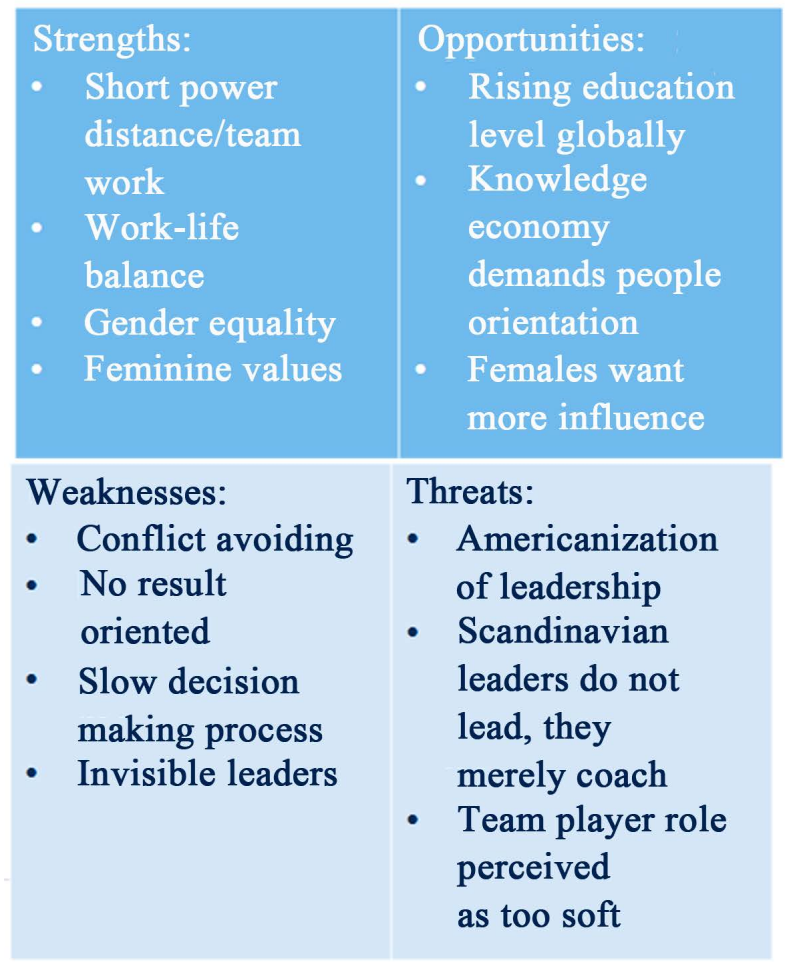

Figure 7. SWOT-analysis of the Scandinavian Management Model. Source: Own representation based on Grenness, 2011, 2003; Zemke, 1988.

\subsection{The Changing Face of the Workplace, Workforce and Leadership}

The digitalization is changing where, why and how we work. Not only business processes are transformed but also next generations grown up with the new technology enter workplaces. They increasingly challenge the existing work organization and values. Elements and values of the Scandinavian Management model, as described in the previous chapter, reflect emerging patterns of the sharing and digital economy and will to a certain extent shape the workplace innovations and management styles. As proper illustration serves Hoffice, a coworking movement founded 2014 in Sweden and already spreading internationally. Freelancers, entrepreneurs, office employees who can work remotely and even people looking for a job meet for work at someone's apartment.

According to the founder of the movement, Swedish psychologist Christopher Franzen, working in houses and apartments is surrounded by a strong collaboration atmosphere and desire to contribute. High autonomy is combined with exchange of ideas and collaboration in relaxed and personal environment. The day starts with the communication of the personal daily goals in order to accomplish more pressure (Peters, 2015). In general, tasks are completed in 45 minutes' slots. The idea builds on empirical studies confirming that people achieve more while working in structured short periods of time During breaks the home workers do yoga, qi gong or simply meditate, network and exchange ideas over 
lunch. At the end of the day, talk goals achievement is discussed (Mok, 2016). Hence, and according to the Hoffice positioning, the movement is creating a productive social working environment as well as a feeling of happiness, inspiration and calm (Mok, 2016).

The success is based on Swedish workplace values like low-level hierarchy and the acceptance for remote work (Savage, 2017). Another driver in the beginning was the shortage of working space in Stockholm and the opportunity of apartment owners to rent out during working hours. The organization and communication reminds of other sharing platforms like Airbnb but with lower formalization. The quick spreading of the movement globally and the establishment of other co-working platforms indicates the rapid transformation of the working place as well as the importance of flexibility for more creativity, productivity and happiness. According to the BBC, Hoffice has almost 1600 members in Sweden and a similar UK based platform Spacehop reports signing up 300 hosts with over 2500 hoppers (Savage, 2017). The launch in India shows that such a movement is influenced by cultural differences, starting from the different perception of privacy and trust letting somebody unknown in your apartment to the flexibility and ease of collective self-organizing. This new phenomenon and how the rise of the shared economy influences the working place, the leadership skills and everyone's productivity and well-being are still not well researched.

As millennials and generation $\mathrm{Z}$ enter the workforce, their behavioral characteristics change work attitudes. Both generations share values such mobility, live for the present, rapid reaction and freedom of information (Bencsik et al., 2016). They have a strong desire for independence and intuitive use of information technology, feel at home everywhere and prefer home office and part time (Bencsik et al., 2016). In short, these characteristics are already shaping the contemporary workplace inducing more flexibility, autonomy, collaboration to social purpose, technology integration and work-life integration (Lipman, 2016).

\subsection{Flexibility}

With the rise of telecommuting and technology tools (like Facebook Work) and a growing productivity pressure workers demand flexibility (Schawbel, 2015). The sharing economy and freelance marketplaces are expanding and professionals have more opportunities for gigs instead of full time jobs. The word gig describes all sorts of flexible employment: Workers are employed on a particular task or for a defined time. The gig economy is driven by cost pressures faced by employers on the one side and the growing desire of employees to have sideexperiences for bigger professional independence (Hansen, 2012).

Professional workers are switching jobs more often and companies are increasingly hiring so-called boomerang employees (leave the company to return later) (Schawbel, 2015). Through technology employers can easily keep in touch with the former and potential talent (through LinkedIn or Facebook). Nonetheless, the gig employment is connected with more job insecurity and regulation for 
worker protection is still rare, although there are first signs in support for more protection by the European Parliament (Bershidsky, 2017). The case of UBER illustrated how protest reactions can lead to regulatory initiatives in numerous countries.

\subsection{Autonomy}

As theory suggests, the more autonomy an employee enjoys the happier he or she is. How to infuse more autonomy in daily work show the examples of $3 \mathrm{M}$ and Google that put aside up to 20 percent of the workweek for employees to work on projects of their own choice. This discretionary time has led to many innovations like the development of Gmail or other innovative applications (Kavanagh, 2016). Autonomy walks hand in hand with accountability and good self-organization. Workforce and management will need to learn how to handle autonomy for achievement of common business goal.

\subsection{Vision and Purpose}

A key for autonomy to be productive is a high engagement. For new generations, the why you do the work you do (Kavanagh, 2016) is of utmost importance. Many companies that concentrate a lot on what and how can enhance on the why-a broader, social purpose.

Again, Google and 3M allow employees to work on tasks that are of personal interest, so-called non-commissioned work time and suggest wide-ranging reforms of the traditional appraisal system (Kavanagh, 2016). Spending spare or part time in voluntary activities with social purpose is spreading and sharing platforms supporting this trend like Neighborland are on the rise (Smedley, 2013). Because of growing importance for employee motivation and engagement, a key quality of a leader is the ability to establish and communicate the why — uniting vision and reason for doing business (Lipman, 2016). This ability concerns being optimistic, thinking that everything is possible, having set shortterm goals to realize the vision, working long hours, having a high-energy level, being not afraid of failure as well as focusing more on the outcome than the process of how something is achieved (Hirsch, 2016).

Entrepreneurial vision is a driving force for the emergence and success of global start-ups (Andersson \& Wictor, 2003). As the examples of Elon Musk, founder of Tesla, Solarcity and several other Silicon Valley companies, show dreaming big and having a powerful vision can combine solutions of complex societal problems, disruption of established capital-intensive car-making and attracting capital and inspiring employees and society (Economist, 2016).

\subsection{Dynamic and Agile Teams}

Flexibility, autonomy and self-determination call for more dynamic work organization. The leading music sharing service Spotify has been leading for several years the ranking of the most popular places to work in Sweden.

$87 \%$ of global staff would recommend the company to a friend, according to a 
study by Glassdoor (Skapinger, 2016).

Employees can find sometimes these autonomous teams chaotic with duplicate and uncoordinated efforts. For this reason, Spotify engages also the socalled agile coaching by team lead to hover over the largely autonomous project teams. Insurance company Simply Business based in UK engages also crossfunction teams to solve problems rather than having purely marketing experts on marketing issues and finance experts in finance. The company was ranked first in the Sunday Times 100 Best Companies to Work for (Chahal, 2016).

\subsection{Constant Collaboration and Networking}

Enhanced by new technology and communication possibilities, broad collaboration and exchange of ideas are driving forces for creativity. On the one side, established companies rub shoulders with starts ups. In London, Google, Barclays or GlaxoSmithKline offer space on their premises to innovators and start-ups or establish dedicated campuses for open innovation (Gaskell, 2016). This allows for meeting interesting people, keeping a closer eye on talent and start up ideas with potential. On the other side, employees are motivated to go out of the office premises and freely collaborate, like the example of the Hoffice movement shows.

Co-working platforms are popular among start-ups, they offer flexible arrangements, and it is about co-operating and not competing, about building communities, exchanging of experiences and learning. Still there is limited research on the intercultural dimensions of digital networking and collaboration. Culture influences the definition of autonomy, time, and flexibility. There is a possibility that this new world of creativity could be possible only in countries and team of similar culture and subculture.

\subsection{Work-Life-Balance}

For millennials and Generation $\mathrm{Z}$ high priority growth opportunities and worklife balance have higher priority over salary, when selecting the company to work for. They look for mentors and supporters-for coaches. Growth is connected with development of knowledge and capabilities as well as freedom to act and create (Bencsik et al., 2016). Technology leads companies to require availability also outside of working hours, working hours are constantly extending and a growing group of employees are suffering a kind of burnout. The importance of a healthy working life is increasing with more technological possibilities to check for breaks and health condition in real time (Schawbel, 2016).

\subsection{Smart Workplaces}

Basic condition for the modern workplace is the availability of the right technology. In the Future Workforce Study organized by Dell and Intel with 3801 respondents from 10 countries, more than $50 \%$, that is, the majority expects to work in a smart office-meaning a more interconnected, agile workforce (Ber- 
nier, 2016). $82 \%$ said that workplace tech would have an influence when they are deciding to take a job (Bernier, 2016). According to other studies, $71 \%$ of the generation aged 16 to 24 want smart devices (Lipman, 2014).

Smart watches or other wearables will be widely used to track personal health but also be more productive while retrieving and organizing information in a 24/7 business environment. Platforms are continuously evolving driven by a collective effort but without wide discussion on what implications, new tools would have on the working place. Popularity of platforms changes and new platform emerge, the tools of the next years are difficult to predict and thus difficult to analyze.

\subsection{Creative Office Design}

Contemporary office design reflects on the above mentioned trends in the work organization: It enhances flexibility, autonomy, collaboration and work-lifebalance and helps attract top talent. Companies are paying extra attention to office environments to make employees more productive and happier at work. Office is becoming more decentralized and space is shrinking (Schawbel, 2015). Knowledge and creative work demand more diverse options and a move away from a single open space. The office design of Google and Facebook internationally has been copied by traditional companies (Wasik, 2016).

Areas are designed for different types of work: creative spaces with walls for writing notes, silence boxes or cubicles where people can concentrate in peace, as well as relaxation rooms with games consoles and spacious kitchens with filled fridges. Companies, property developers and designers confirm that the office today supports the creativity and collaboration as well as work efficiency increases when no one imposes where they have to work (Wasik, 2016). Dutch company Heldegroen goes so far that every day at 6:00 pm all boards disappear-they are being pulled up to force employees to go home (Thomas, 2014).

\subsection{Global Entrepreneurs as Leadership Role Model}

The described trends in the workforce and workplace are accompanied of changes of management style and challenges for traditional leadership models. With the rise of the sharing economy and quickly internationalizing start-up businesses that disrupt existing ones, a new role model of the global entrepreneur attracts attention. Epitomized by the founders of Facebook, Google, Tesla, Spotify or Airbnb these leaders set new standards as their companies became the most popular choices for work internationally (Dill, 2015). Global entrepreneurs establish and manage small size start-ups that grow fast on a global scale often transforming whole industries (Cavusgil \& Knight, 2014). Their defining skills are embracing change, ability to establish a vision, high tolerance of ambiguity and integrity, knowledge of the importance of individuals (Hirsch, 2016). They empower others to act independently on their tasks establishing flatter hierarchies, care for their employee's wellbeing and give them the freedom and flex- 
ibility over their work-life balance (Andersson \& Florén, 2009). The new leadership style is also a reflective one, so that present business is developed with energy and focus and at the same time emerging opportunities for future business are reflected on.

\subsection{Inclusive and Reflective Leadership}

Research confirms the need for more inclusive and supportive leadership models that contribute to employee's sense of belonging, engagement and job satisfaction (Chahal, 2016). According to the UK-based insurance company Simply Business, ranked Company No. 1 in the Sunday Times 100 Best Companies to Work for, including best leader award, a company has to create mere the conditions for everyone's success than trying to define the success for each employee. When the company gives employees the freedom to choose the tasks and projects they work on and how they accomplish them, a bond of trust is created. Research reveals strong relationship between inclusive leadership and self-ratings of performance, productivity, satisfaction and engagement (Prime \& Salib, 2014). Inclusive leadership allows for higher priority to be put on explore-develop new products, services and markets, than on exploit focusing on control of cost and procedures (Chahal, 2016).

\subsection{Managing a Virtual Team}

With activities spread over self-organizing autonomous teams and talented individuals, a global entrepreneur requires the ability to build and manage a virtual team. Grown up in the atmosphere of spontaneous collaboration and mastering the art of social networking, global entrepreneurs are well equipped to understand the dynamics of a virtual team and the qualities the team members need to have. For effective team management, coordinated times, prepared agenda with priorities and supporting materials are required as well as time to develop relationships with everyone for example by sharing personal information (Hirsch, 2016). As the importance of self-organization is increasingly questioned by generation Z, a successful global entrepreneur should be able to set clear goals and manage chaos without damaging a creative and collaborative atmosphere. For example, Google sees employee failures as a way of learning and employees should think by themselves in order to come up with creative ideas to solve problems (Hirsch, 2016).

\subsection{Transparency}

Not only clarity about the vision but also growing importance of transparency in daily business changes management style. Employees are grown up with widely available and accessible information (Lipman, 2016) and demand it also in respect of the business they are working for. Two UK based examples illustrate a new approach to internal communication (Chahal, 2016). At Skyscanner, a leading travel search site, the CEO attends employee briefings, holds monthly 
town halls and blogs regularly. At Webmart, a print solution provider, the CEO records weekly bizcast for employees and provides access to unedited meeting notes and financial results.

\subsection{Coaching and Empowering Self-Development}

Some think that entrepreneurs are born but studies such as the one from EY (2011) stress that they are made rather than born. The EY study conducted with ten entrepreneurs highlights that an entrepreneur gains experience through education and working for others which can then help him or her to acquire the knowledge they need in order to start their own business. It is natural to coach back, breed an entrepreneurial spirit and empower employees to take charge of their personal development. For example, at Skyscanner internal corporate education is a top management task: The CEO holds a five-week program for high performing employees on entrepreneurial thinking and chief operating officer organizes a seven-week program on leadership in practice (Chahal, 2016). When summarizing the challenges for leadership styles, leadership development should focus on skills such as coaching and mentoring, communication of values, collaboration and developing means and techniques to help employees to find their own development path.

\section{Discussion}

Most of the described new trends and developments are not well researched and controversial. Therefore, it is still unclear how the rise of the shared economy influences the working place, the leadership skills and everyone's productivity. In addition to this, future research could deal with the impact of regulation on the gig economy and further investigate what kind of regulation could be effective for global start-ups.

Likewise, future research could shed light on new technology tools. For example, platforms are continuously evolving but without wide discussion on what implications new tools would have on the working place. As recent events have shown, only after a feature is publicly criticized a new development follows. Nevertheless, the popularity of platforms changes over time and the tools of the next years are difficult to predict and thus difficult to analyze.

The same holds for the evolvement of working processes because of the digitalization and the disappearance of whole process steps as well as the emergence of new job descriptions-all of which make it extremely difficult for a serious long-term research.

Another point worth discussing in this context are intercultural challenges. Even with no geographic borders, there exist a wide range of different definitions of autonomy, time, and flexibility in different cultures. This phenomenon might be linked with intercultural problems that could arise and should therefore be further investigated. Another risk that might occur is that the new beautiful world of autonomy, flexibility and creativity could only be realized in coun- 
tries or subcultures sharing similar values and backgrounds.

However, recent scandals in global start-ups like UBER shattered the glamourous image of the whole tech industry, which has been the trendsetter in terms of work processes, technology solutions and leadership styles. In general, an increasing wave of regulation is to be expected. Nevertheless, the impact of the possible new regulation on the business models and the working processes as well as culture remains to be seen.

\section{Conclusions}

Whereas the Industrial Revolution separated housing and workplaces, the Digital Revolution seems to again bring together both areas of life. Not only can we today observe major shifts of risks and responsibilities from the employer to the employee through, for example, more project-related work, often team work goes in line with flatter hierarchies or, more generally, a decentralization of the organization of work.

Against this background, softer and at the same time smarter solutions appear to be a good mechanism to adapt to the increasing changes as regards the workplace. Coping with the challenges of the Digital Revolution might be successful through further developing entrepreneurial attitudes, as for instance exemplified by the picture of the intrapreneur from Pinchot (1985).

During the investigation, the authors detected comparably good results of the Scandinavian member states of the European Union. Therefore, light was shed on the particular Scandinavian Management Model, as this approach appeared to be better prepared for the future than other models.

Surprisingly, the consensus and cooperative management style, where many decisions are made through democratic processes and a rather participative leadership style, revealed many similarities in view of modern workplaces, which we find today-not only in Europe.

By using the latest insights regarding successful companies tackling the demands of the Digital Revolution, it is shown that by using more flexible and autonomous work arrangements, a constant collaboration and networking can be triggered. Thereby, smart workplaces, including often creative office designs, evolve. Entrepreneurial skills together with the willingness to gradually take on more responsibility for oneself both on the job and during free time become increasingly important.

This might also result in a more inclusive and reflective leadership style, as employees today grow up with widely accessible information. That is, the coaching and empowering of self-development is likely to become a distinct feature of modern day managers.

Given the different stages of development in view of the various world regions, a widespread use of the suggested management methods appears to be overambitious and not workable. With this in mind, it remains to be seen whether a certain management method will prevail in the long run. In addition, 
it is highly questionable whether a "one-size-fits-all" approach will meet the requirements of the diverse management styles in the world.

\section{References}

Andersson, S., \& Florén, H. (2009). Exploring Differences in the Work of Owner Managers in Small International and Non-International Firms. In 12 th McGill International Entrepreneurship Conference (pp. 18-20).

Andersson, S., \& Wictor, I. (2003). Innovative Internationalisation in New Firms: Born Globals-The Swedish Case. Journal of International Entrepreneurship, 1, 249-275. https://doi.org/10.1023/A:1024110806241

Averill, J. (1973). Personal Control over Aversive Stimuli and Its Relationship to Stress. Psychological Bulletin, 80, 286-303. https://doi.org/10.1037/h0034845

Bencsik, A. et al. (2016). Y and Z Generations at Workplaces. Journal of Competitiveness, 8, 90-106.

Bernier, L. (2016). Employees Looking for “Smart” Workplaces. ProQuest.

Bershidsky, L. (2017). Europe Will Defend Its Gig Economy Workers. https://www.bloomberg.com/view/articles/2017-01-19/europe-stands-up-for-gig-econo my-workers

Blank, G., \& Groselj, D. (2014). Dimension of Internet Use: Amount, Variety, and Types. Information, Communication \& Society, 17, 417-435. https://doi.org/10.1080/1369118X.2014.889189

Brynjolfsson, E., \& Mc Affee, A. (2011). Race against the Machine: How the Digital Revolution Is Accelerating Innovation, Driving Productivity, and Irreversibly Transforming Employment and the Economy. Lexington, MA: Digital Frontier Press.

Brynjolfsson, E., \& Mc Affee, A. (2014). The Second Machine Age: Work, Progress and Prosperity in a Time of Brilliant Technologies. New York, NY: W. W. Norton \& Company.

Cavusgil, T. S., \& Knight, G. (2014). The Born Global Firm: An Entrepreneurial and Capabilities Perspective on Early and Rapid Internationalization. Journal of International Business Studies, 46, 3-16.

Chahal, M. (2016). The New Era of Leadership: The Management Styles Unlocking Unique Ways of Thinking. http://www.marketingweek.com/2016/04/29/the-new-era-of-leadership

Deci, E., \& Ryan, R. (1985). Intrinsic Motivation and Self-Determination in Human Behavior. New York, NY: Springer. https://doi.org/10.1007/978-1-4899-2271-7

Deci, E., \& Ryan, R. (2000). Self-Determination Theory and the Facilitation of Intrinsic Motivation, Social Development, and Well-Being. American Psychologist, 55, 68-78. https://doi.org/10.1037/0003-066X.55.1.68

Dill, K. (2015). The Best Places to Work in 201. http://www.forbes.com/sites/kathryndill/2015/12/14/the-best-places-to-work-in-2016

Economist (2016). Can Elon Musk's Business Empire Survive and Thrive? http://www.economist.com/blogs/economist-explains/2016/10/economist-explains-21

Eichhorst, W. (2015). Do We Have to Be Afraid of the Future World of Work? IZA Policy Paper No. 102.

Eichhorst, W. et al. (2011). Cross-Border Collective Bargaining and Transnational Social Dialogue. IZA Research Report No. 38. 
European Commission (2013). Commission Staff Working Document. Digital Agenda Scoreboard 2013.

Evans, G., \& Carrére, S. (1991). Traffic Congestion, Perceived Control, and Psychophysiological Stress among Urban Bus Drivers. Journal of Applied Psychology, 76, 658-663. https://doi.org/10.1037/0021-9010.76.5.658

EY (2011). Nature or Nurture? Decoding the DNA of the Entrepreneur (Vol. CY0167, Rep.). London: Ernst \& Young.

Frey, C., \& Osborne, M. (2015). Technology at Work. The Future of Innovation and Employment. Citi GPS: Global Perspectives \& Solutions.

Gagné, M., \& Bhave, D. (2011). Autonomy in the Workplace: An Essential Ingredient to Employee Engagement and Well-Being in Every Culture. In: V. I. Chirkov, R. M. Ryan, \& K. M. Sheldon (Eds.), Human Autonomy in Cross-Cultural Context: Perspectives on the Psychology of Agency, Freedom, and Well-Being (pp.163-187). Berlin: Springer.

Gagné, M., \& Deci, E. (2005). Self-Determination Theory as a New Framework for Understanding Organizational Behaviour. Journal of Organizational Behavior, 26, 331-362. https://doi.org/10.1002/job.322

Gallie, D., \& Zhou, Y. (2013). Job Control, Work Intensity and Work Stress. In D. Gallie (Ed.), Economic Crisis, Quality of Work and Social Integration: The European Experience (pp. 115-141). Oxford: Oxford University Press. https://doi.org/10.1093/acprof:oso/9780199664719.001.0001

Ganster, D., \& Fusilier, M. (1989). Control in the Workplace. In C. Cooper, \& I. Robertson (Eds.), International Review of Industrial and Organizational Psychology (pp. 235-280). Chichester: Wiley.

Gaskell, A. (2016). The Changing Shape of the Modern Workplace. https://www.forbes.com/sites/adigaskell/2016/08/15/the-changing-shape-of-the-moder n-workplace/\#e529f6023e5c

Grenness, T. (2003). Scandinavian Managers on Scandinavian Management. International Journal of Value-Based Management, 16, 9-21. https://doi.org/10.1023/A:1021977514976

Grenness, T. (2011). Will the "Scandinavian Leadership Model" Survive the Forces of Globalisation? A Swot Analysis. International Journal of Business and Globalisation, 7, 332-350. https://doi.org/10.1504/IJBG.2011.042062

Hackman, J. (1986). The Psychology of Self-Management in Organizations. In R. Pallack, \& R. Perloff (Eds.), Psychology and Work: Productivity, Change and Employment (pp. 89-136). Washington DC: American Psychological Association. https://doi.org/10.1037/10055-003

Hackman, J., \& Oldham, G. (1975). Development of the Job Diagnostic Survey. Journal of Applied Psychology, 60, 159-170. https://doi.org/10.1037/h0076546

Hansen, T. (2012). The Future of Knowledge Work. Intel Labs White Paper. http://download.intel.com/newsroom/kits/research/2012/pdfs/The_Future_of_Knowle dge_Work-Intel_WhitePaper.pdf

Hirsch, R. D. (2016). International Entrepreneurship (3rd ed.). Los Angeles, CA: SAGE.

Karasek, R. (1979). Job Demands, Job Decision Latitude and Mental Strain: Implications for Job Redesign. Administrative Science Quarterly, 24, 285-308. https://doi.org/10.2307/2392498

Kavanagh, S. (2016). Motivating the Modern Workforce. Government Finance Review, 32, 52. 
Levy, F., \& Murnane, R. J. (2004). The New Division of Labor: How Computers are Creating the Next Job Market. Princeton and Oxford: Princeton University Press.

Lipman, V. (2016). Key Management Trends for 2016? Here Are 6 Research-Based Predictions.

https://www.forbes.com/sites/victorlipman/2016/01/01/key-management-trends-for-20 16-here-are-6-research-based-predictions/\#47969a47de44

Luchman, J., \& Gonzalez-Morales, M. (2013). Demands, Control, and Support: A Meta-Analytic Review of Work Characteristics Interrelationships. Journal of Occupational Health Psychology, 18, 37-52. https://doi.org/10.1037/a0030541

Malthus, T. (1798). An Essay on the Principle of Population. London: Oxford University Press.

Miller, S. (1979). Controllability and Human Stress: Method, Evidence and Theory. Behavior Research and Therapy, 17, 287-304.

https://doi.org/10.1016/0005-7967(79)90001-9

Mok, K. (2016). Hoffice Project Lets People Share Their Homes as Free Co-Working Spaces. http://www.treehugger.com/culture

Peters, A. (2015). Hoffice Turns Your Apartment into a Free and Incredibly Productive-Coworking Space. https://www.fastcoexist.com/3041322

Piketty, T. (2014). Capital in the Twenty-First Century. Cambridge, MA: Harvard University Press. https://doi.org/10.4159/9780674369542

Pinchot, G. (1985). Why You Don't Have to Leave the Corporation to Become an Entrepreneur. Oakland, CA: Berrett-Koehler Publisher.

Prime, J., \& Salib, E. R. (2014). Inclusive Leadership: The View from Six Countries. A Catalyst Report 2014.

http://www.catalyst.org/system/files/inclusive_leadership_the_view_from_six_countrie s_0.pdf

Rifkin, J. (1995). The End of Work: The Decline of the Global Labor Force and the Dawn of the Post-Market Era.

Savage, M. (2017). The Swedish Ditching Desks to Work from Strangers' Homes. http://www.bbc.com/capital/story/20161230-the-swedes-ditching-desks-to-work-fromstrangers-homes

Schawbel, D. (2015). 10 Workplace Trends You'll See in 2016. http://www.forbes.com/sites/danschawbel/2015/11/01/10-workplace-trends-for-2016

Simon, H. (1960). The Corporation: Will It Be Managed by Machines? In M. Anshen, \& G. Bach (Eds.), Management and the Corporations 1985 (pp. 1755). Toronto, London, New York, NY: ABC-CLIO.

Skapinger, M. (2016). Spotify and Amazon Show Modern Work's Sharp Divide. ProQuest.

Smedley, T. (2013). Facebook for Volunteering: The Rise of Online Community Action. https://www.theguardian.com/voluntary-sector-network/2013/dec/06/facebook-for-vol unteering-online-city-planning

Sparks, K. et al. (2001). Well-Being and Occupational Health in the 21st Century Workplace. Journal of Occupational and Organizational Psychology, 74, 489-509. https://doi.org/10.1348/096317901167497

Stansfeld, S., \& Candy, B. (2006). Psychological Work Environment and Mental Health-A Meta-Analytic Review. Scandinavian Journal of Work, Environment \& Health, 32, 443-462. https://doi.org/10.5271/sjweh.1050 
Terry, D., \& Jimmieson, N. (1999). Work Control and Employee Well-Being: A Decade Review. In C. Cooper, \& I. Robertson (Eds.), International Review of Industrial and Organizational Psychology (p. 14). Chichester: Wiley.

Thomas, E. (2014). These Office Desks Vanish after 6 P.M., Opening up Yoga Space. http://www.huffingtonpost.com/2014/09/18/heldergroen-office-disappears-after-6_n_5 844106.html

Wall, T. et al. (1986). Outcomes of Autonomous Workgroups: A Long-Term Field Experiment. Academy of Management Journal, 29, 280-304. https://doi.org/10.2307/256189

Wasik, Z. (2016). Warsaw Millennials Want Creature Comforts. ProQuest.

Zemke, R. (1988). Scandinavian Management-A Look at Our Future? Management Review, 77, 44-47. 